\title{
DsbB Is Required for the Pathogenesis Process of Xanthomonas campestris pv. campestris
}

\author{
Bo-Le Jiang,,$^{1,2}$ Jiao Liu, ${ }^{1}$ Li-Feng Chen, ${ }^{1}$ Ying-Ying Ge, ${ }^{1}$ Xiao-Hong Hang, ${ }^{1}$ Yong-Qiang He, ${ }^{1,2}$ \\ Dong-Jie Tang, ${ }^{1,2}$ Guang-Tao Lu, ${ }^{1,2}$ and Ji-Liang Tang ${ }^{1,2}$ \\ ${ }^{1}$ College of Life Science and Technology, Guangxi University, China; ${ }^{2}$ Guangxi Key Laboratory of Subtropical Bioresources \\ Conservation and Utilization and The Key Laboratory of Microbial and Plant Genetic Engineering, 100 Daxue Road, \\ Nanning, Guangxi 530004, China
}

Submitted 2 February 2008. Accepted 22 April 2008.

\begin{abstract}
The DsbA/DsbB oxidation pathway is one of the two pathways that catalyze disulfide bond formation of proteins in the periplasm of gram-negative bacteria. It has been demonstrated that DsbA is essential for multiple virulence factors of several animal bacterial pathogens. In this article, we present genetic evidence to show that the open reading frame XC_3314 encodes a DsbB protein that is involved in disulfide bond formation in periplasm of Xanthomonas campestris pv. campestris, the causative agent of crucifer black rot disease. The $d s b B$ mutant of $X$. campestris pv. campestris exhibited attenuation in virulence, hypersensitive response, cell motility, and bacterial growth in planta. Furthermore, mutation in the $d s b B$ gene resulted in ineffective type II and type III secretion systems as well as flagellar assembly. These findings reveal that DsbB is required for the pathogenesis process of $X$. campestris pv. campestris.
\end{abstract}

Dsb proteins of gram-negative bacteria are a group of proteins that catalyze disulfide bond formation in the periplasm of cells. Disulfide bond formation is essential for the tertiary and quaternary structures of many extracytoplasmic proteins containing more than one cysteine residue. Among the Dsb proteins, DsbA and DsbB form a catalytic cascade pathway in which DsbA, a periplasmic thiol:disulfide oxidoreductase, catalyzes oxidative protein folding, while DsbB, an integral component of the cytoplasmic membrane, recycles reduced DsbA to the active oxidized form (Collet and Bardwell 2002; Kadokura et al. 2003; Łasica and Jagusztyn-Krynicka 2007; Messens and Collet 2006; Nakamoto and Bardwell 2004).

Pathogenic bacteria secrete numerous virulence factors to host cells during infection. In the secretion process, many of the virulence factors need to be structurally modified via disulfide bond formation in the periplasm. Some of the components constituting secretion pathways may also be post-translationally modified through disulfide bond formation. Studies on the relationship between the Dsb system and the pathogenesis process of bacteria have been mainly carried out for animal pathogens. It has been demonstrated that DsbA is involved in toxin production of Bordetella pertussis (Stenson and Weiss 2002), Escherichia coli (Hardy and Hedges 1996; Okamoto et al. 1998), and Vibrio cholerae (Yu et al. 1992); adhesion of $E$. coli (Zhang and Donnenberg 1996), Neisseria meningitides (Tinsley et al. 2004), and Salmonella enterica (Bouwman et al. 2003); motility of E. coli (Hiniker and Bardwell 2004), Pseu-

Corresponding author: Ji-Liang Tang; Telephone: 86-771-3239566; Fax: 86-771-3239413; E-mail: jlt@gx163.net or jltang@gxu.edu.cn domonas aeruginosa (Ha et al. 2003), and S. enterica (Agudo et al. 2004); extracellular enzyme production of $P$. aeruginosa (Braun et al. 2001; Urban et al. 2001); and type III secretion system of $P$. aeruginosa (Ha et al. 2003), S. enterica (Altmeyer et al. 1993; Miki et al. 2004), Shigella flexneri (Watarai et al. 1995; Yu et al. 2000), and Yersinia pestis (Jackson and Plano 1999). Little work has been involved in investigation of the role of DsbB in pathogenicity. The only example is the study of the effect of DsbB on the cell motility of E. coli (Dailey and Berg 1993) and Campylobacter jejuni (Raczko et al. 2005). It was found that the $d s b B$ mutant of $E$. coli failed to assemble functional flagella (Dailey and Berg 1993). The $d s b B$ and $d s b I$ (a $d s b B$ paralog) double mutant of $C$. jejuni did not form flagella, although a mutation in either $d s b B$ or $d s b I$ did not reduce the motility of the pathogen (Raczko et al. 2005).

Apart from the observations that mutation in the $d s b A$ gene of the plant pathogen Erwinia chrysanthemi affected the stability of the virulence factors, the plant cell-wall-degrading enzymes cellulase and pectinase (Shevchik et al. 1995), and mutation in the $d s b A$ and $d s b C$ genes of E. carotovora had multiple effects on extracellular enzymes and cell motility (Vincent-Sealy et al. 1999), little is known about the role of $d s b$ genes in the pathogenesis process of phytopathogenic bacteria. The recent rapid development of genomics has brought about a paradigm shift in gene function research. After determination of the genome of Xanthomonas campestris pv. campestris (Qian et al. 2005), we have made an effort to explore the role of $d s b$ genes in pathogenicity of the pathogen. $X$. campestris pv. campestris is the causal agent of black rot disease, one of the most destructive diseases of cruciferous plants worldwide (Alvarez 2000). This pathogen infects almost all the members of crucifer family (Brassicaceae), including important vegetables such as broccoli, cabbage, cauliflower, mustard, and radish; the major oil crop, rape; as well as the model plant Arabidopsis thaliana, and has been used as a model bacterium to study molecular microbe-plant interactions for over two decades. In this article, we present genetic evidence to demonstrate that the $d s b B$ gene is essential for full virulence of $X$. campestris pv. campestris and involved in cell motility and type II and type III secretion systems.

\section{RESULTS}

XC_3314 of the $X$. campestris pv. campestris 8004 may encode a DsbB protein.

In the reported genome sequence of the X. campestris pv. campestris 8004, the open reading frame (ORF) XC_3314 (GenBank accession number YP_244378) was annotated to 
encode a disulfide bond formation protein B (DsbB) (Qian et al. 2005). The ORF XC_3314 is located in anti-clockwise orientation of the genome sequence between position 3969633 and position 3970151 of the X. campestris pv. campestris 8004 (Qian et al. 2005). The nearest ORF upstream and downstream of XC_3314 are XC_3315 (encoding a putative 50S ribosomal protein L17) and XC_3313 (encoding a putative 3-deoxy-7phosphoheptulonate synthase), respectively. Sequence comparison search showed that no other ORF in the genome of the $X$. campestris pv. campestris 8004 display homologous DNA sequences with the ORF XC_3314. The deduced protein XC3314, consisting of 172 amino acid residues, shares 38.9 and $28.6 \%$ amino acid similarity and identity, respectively, with the DsbB protein of $P$. aeruginosa PAO1 (NP_249229) (Fig. 1A). A redox active Cys-X-X-Cys motif, the typical conserved motif for the Dsb protein family (Fabianek et al. 2000; Kadokura et al. 2003), is embedded between the 38th and 41st amino acid residues of the XC3314 protein (Fig. 1A). Transmembrane helices analysis of XC3314 showed that the protein spans the membrane four times with both $\mathrm{N}$ and $\mathrm{C}$ termini facing the cytoplasm (Fig. 1B), which is in accordance with identified DsbBs (Jander et al. 1994; Kadokura et al. 2003). These results from bioinformatics analyses suggest that the deduced protein of the ORF XC_3314 may be a DsbB protein.

A

XC3314

PA01 DsbB

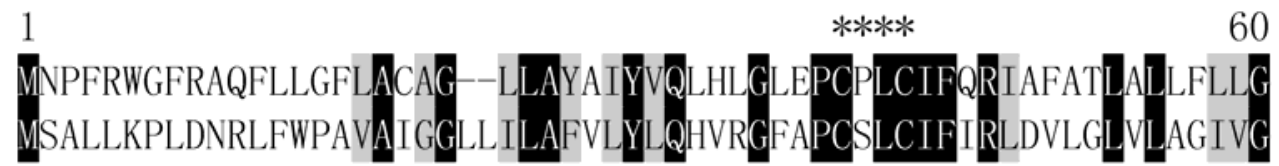

XC3314

PA01 DsbB

61
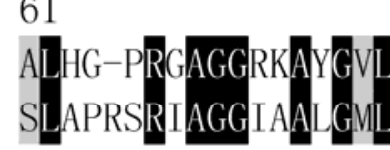

121

XC3314

(118)

PA01 DsbB

(118)

FEVFRTVLTGTGDCGNIDWRFLGLSMPMWSMVWFVGLALWALYAGFKHRGPRKLF DTWLPQVFQPEGLCGEVVWTLLGQSMAVWSLALFVFCLLVLAAKLAFGRRTA---

B
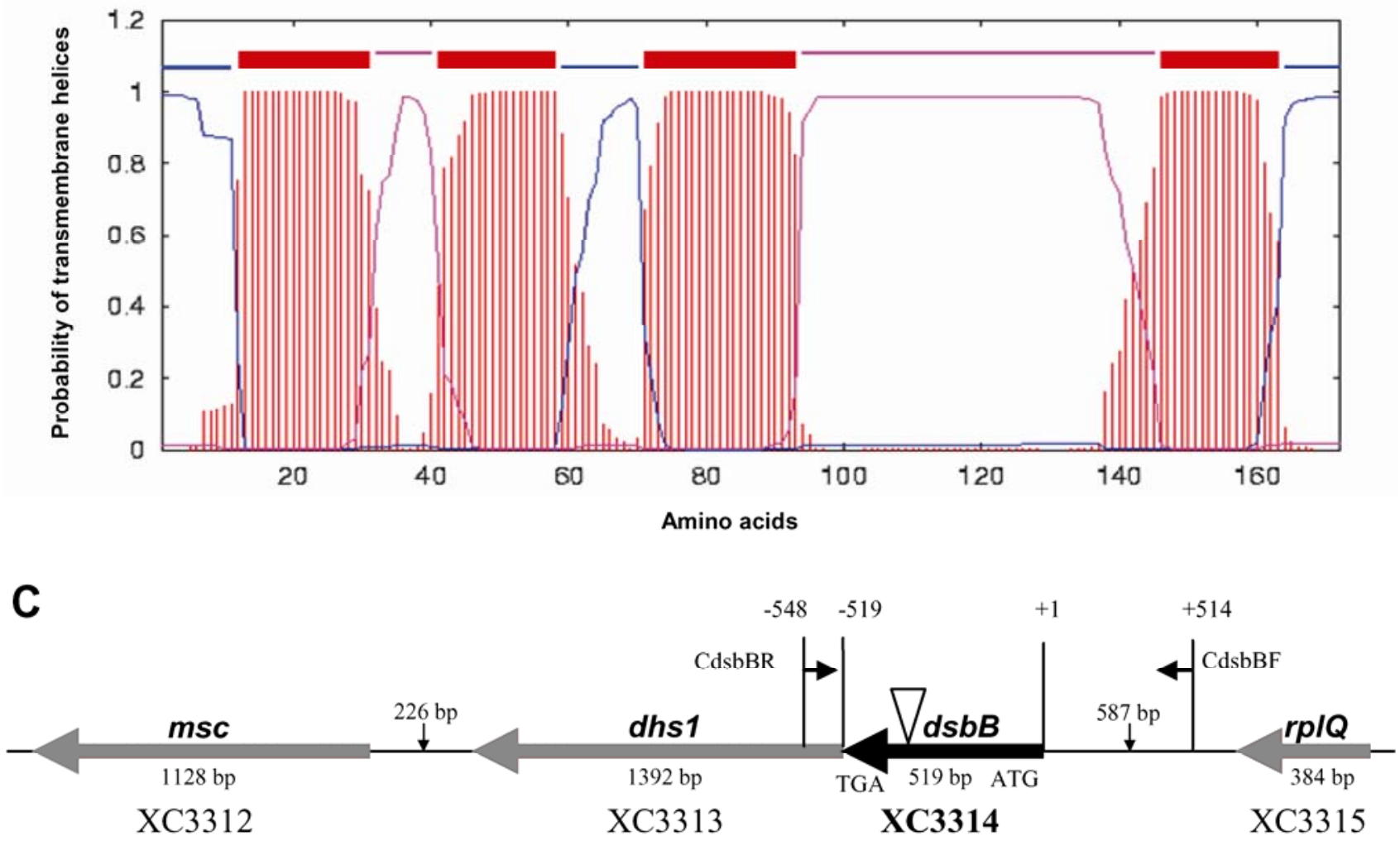

Fig. 1. Bioinformatics analyses of Xanthomonas campestris pv. campestris DsbB. A, Alignment of amino acid sequence of DsbB homologs from X. campestris pv. campestris 8004 and Pseudomonas aeruginosa PAO1. The GenBank accession numbers of the P. aeruginosa DsbB and the X. campestris. pv. campestris DsbB were NP_249229 and YP_244378, respectively. Black boxes denote identical amino acid residues, whereas gray-shaded boxes are similar between the two sequences. The starred area denotes the typical redox active -Cys-X-X-Cys- motif of the disulfide bond formation protein family. B, Prediction of transmembrane helices in the X. campestris. pv. campestris DsbB. This was analyzed with TMHMM Server v. 2.0 software. Red blocks stand for the transmembrane helices in cytoplasmic membrane while pink threads for periplasmic loops and blue for regions inside the cytoplasm. $\mathbf{C}$, Physical and genetic map of the $X$. campestris. pv. campestris $d s b B$ region. The black arrowhead stands for the $d s b B$-encoding open reading frame XC_3314. The empty triangle denotes the position of the transposon Tn5gusA5 inserted in the mutant strain 077F07. The small arrows represent the position and direction of the primers used to amplify the fragment for construction of the complemented strain C077F07. 
It has been demonstrated that mutations of the $d s b B$ gene cause the accumulation of DsbA in its reduced form and exhibit the same pleiotropic phenotype as the $d s b A$ mutant (Kadokura et al. 2003; Missiakas et al. 1993). In order to validate further whether the ORF XC_3314 encodes a DsbB protein and study its role in pathogenicity of $X$. campestris pv. campestris, we screened the mutant library of the $X$. campestris pv. campestris 8004 , which was constructed by transposon Tn5gusA5 insertion mutagenesis in our laboratory (details below), for an XC_3314 mutant. A mutant, named 077F07 (Table 1), with a single Tn5gusA5 insertion in the ORF XC_3314 (Fig. 1C) was obtained. A complemented strain, designated as C077F07, was constructed in this study by transferring the recombinant plasmid pXC3314, which carries an entire wildtype XC_3314 gene, into the mutant 077F07 (Table 1) (details below). To ascertain whether mutation in XC_3314 has any effect on the growth of $X$. campestris pv. campestris, we tested the growth of the XC_3314 mutant strain 077F07 and the wild-type strain 8004 in the minimal medium MMX (Daniels et al. 1984b) and the rich medium NYGB (Daniels et al. 1984a) with and without shaking, respectively. The results showed that 077F07 and 8004 grew identically in both media with or without shaking (data not shown), indicating that XC_3314 is not required for the growth of X. campestris pv. campestris in standard media.

To determine whether disruption of the XC_3314 gene has any effect on the formation of disulfide in the periplasmic proteins, we examined the free thiol groups in the periplasm by measuring the accumulation of proteins with reduced cysteines in periplasm of the XC_3314 mutant with Ellman's reaction method (Riddles et al. 1979). The periplasmic protein samples were isolated by the chloroform method (Ames et al. 1984) and incubated with excess Ellman's reagent (details below). The result showed that more proteins with free thiols were accumulated in the periplasm of the XC_3314 mutant strain $077 \mathrm{~F} 07$ than that of the wild-type strain 8004 (Fig. 2A). In addition, the mutant strain 077F07 was more sensitive to the strong reducing agent dithiothreitol (DTT) than the wild-type strain (Fig. 2B). These phenotypes of the mutant could be restored to wild type by the pLAFR6-recombinant plasmid pXC3314 harboring the entire XC_3314 gene (Fig. 2). The vector plasmid pLAFR6 alone had no effect on the phenotypes of the $d s b B$ mutant and the wild-type strain, including all of the phenotypes tested below (data not shown). All of these results indicate that the ORF XC_3314 may encode a DsbB protein that is involved in disulfide bond formation in periplasm of $X$. campestris pv. campestris. Therefore, we designated the $\mathrm{XC} \_3314$ gene as $d s b B$.

\section{DsbB is essential for full virulence and hypersensitive response of $X$. campestris pv. campestris.}

To investigate the role of DsbB in pathogenicity of $X$. campestris pv. campestris, we tested the virulence and hypersensitive response (HR) of the $d s b B$ mutant strain $077 \mathrm{~F} 07$ on host plant Chinese radish and nonhost plant pepper ECW-10R, respectively. The results showed that the $d s b B$ mutant exhibited a significant reduction in virulence compared with the wild-type strain (Fig. 3A). Ten days postinoculation by leaf clipping, the $d s b B$ mutant caused disease symptoms with a mean lesion length of only $4.7 \mathrm{~mm}$, whereas the wild type caused a mean lesion length of $13.1 \mathrm{~mm}$ (Fig. 3B). The mean lesion lengths caused by the complemented strain C077F07 and the wild-type strain 8004 were not significantly different $(P=0.05$ by $t$ test) (Fig. 3B). For the HR test on pepper ECW$10 \mathrm{R}$, the $d s b B$ mutant strain $077 \mathrm{~F} 07$ could not produce a visible HR phenotype $24 \mathrm{~h}$ after inoculation but the complemented strain C077F07 caused a typical wild-type HR (Fig. 3C). The results demonstrate that $\mathrm{DsbB}$ is essential for full virulence and HR of $X$. campestris pv. campestris.

To explore the role of $d s b B$ in the growth of $X$. campestris pv. campestris in the host plant, we determined the population of the $d s b B$ mutant strain 077F07, the wild-type strain 8004, and the complemented strain $\mathrm{C} 077 \mathrm{~F} 07$ in Chinese radish. The number of the bacterial cells of the $d s b B$ mutant recovered

Table 1. Bacterial strains and plasmids used in this work ${ }^{\mathrm{a}}$

\begin{tabular}{|c|c|c|}
\hline Strains or plasmids & Relevant characteristics & Reference \\
\hline \multicolumn{3}{|c|}{ Xanthomonas campestris pv. campestris } \\
\hline 8004 & Wild type, Rif $^{\mathrm{T}}$ & Daniels et al. 1984a \\
\hline 8005/pPH1JI & 8005 harboring $\mathrm{pPH} 1 \mathrm{JI}, \mathrm{Spc}^{\mathrm{r}}, \mathrm{Gm}^{\mathrm{r}}$ & Turner et al. 1985 \\
\hline 077F07 & XC_3314 Tn5gusA5 insertion mutant of 8004, $\operatorname{Rif}^{\mathrm{r}}, \mathrm{Kan}^{\mathrm{r}}, \mathrm{Spc}^{\mathrm{r}}, \mathrm{Gm}^{\mathrm{r}}$ & Our lab's collection \\
\hline C077F07 & 077F07 harboring pXC3314, Rif $^{\mathrm{r}}, \mathrm{Kan}^{\mathrm{r}}, \mathrm{Tc}^{\mathrm{r}}$ & This study \\
\hline$\Delta \mathrm{dsbB}$ & XC_3314 pK18mob integration mutant of $8004, \operatorname{Rif}^{\mathrm{r}}, \mathrm{Kan}^{\mathrm{r}}$ & This study \\
\hline $001 \mathrm{~F} 10$ & XC_3379 Tn5gusA5 insertion mutant of 8004, prt $^{-}, \operatorname{Rif}^{\mathrm{r}}, \mathrm{Kan}^{\mathrm{r}}, \mathrm{Gm}^{\mathrm{r}}, \mathrm{Spc}^{\mathrm{r}}$ & Our lab's collection \\
\hline 069G09 & XC_0141 Tn5gusA5 insertion mutant of 8004, amy ${ }^{-}, \mathrm{Rif}^{\mathrm{r}}, \mathrm{Kan}^{\mathrm{r}}, \mathrm{Gm}^{\mathrm{r}}, \mathrm{Spc}^{\mathrm{r}}$ & Our lab's collection \\
\hline 285D12 & XC_3563 Tn5gusA5 insertion mutant of 8004, xpsD $D^{-}, \mathrm{Rif}^{\mathrm{r}}, \mathrm{Kan}^{\mathrm{r}}, \mathrm{Gm}^{\mathrm{r}}, \mathrm{Spc}^{\mathrm{r}}$ & Our lab's collection \\
\hline 050B12 & $h r c \bar{V}$ Tn5gusA5 insertion mutant of $8004, \mathrm{HR}^{-}, \mathrm{Rif}^{\mathrm{r}}, \mathrm{Kan}^{\mathrm{r}}, \mathrm{Gm}^{\mathrm{r}}, \mathrm{Spc}^{\mathrm{r}}$ & Our lab's collection \\
\hline$\Delta \mathrm{hrcV}$ & $h r c V$ pK18mob integration mutant of 8004, $\operatorname{Rif}^{\mathrm{r}}, \mathrm{Kan}^{\mathrm{r}}$ & This study \\
\hline 8004/pLGUS0241 & 8004 containing pLGUS0241, Rif $^{\mathrm{r}}, \mathrm{Tc}^{\mathrm{r}}$ & This study \\
\hline$\Delta \mathrm{hrcV} / \mathrm{pLGUS0241}$ & $\Delta \mathrm{hrcV}$ containing pLGUS0241, $\operatorname{Rif}^{\mathrm{r}}, \operatorname{Kan}^{\mathrm{r}}, \mathrm{Tc}^{\mathrm{r}}$ & This study \\
\hline$\Delta \mathrm{dsbB} / \mathrm{pLGUS0241}$ & $\Delta \mathrm{dsbB}$ containing pLGUS0241, $\operatorname{Rif}^{\mathrm{r}}, \mathrm{Kan}^{\mathrm{r}}, \mathrm{Tc}^{\mathrm{r}}$ & This study \\
\hline \multicolumn{3}{|l|}{ Escherichia coli } \\
\hline JM109 & $\begin{array}{l}\text { RecAl, endA1, gyrA96, thi, supE44, relA1, } \Delta(\text { lac-proAB }) / F^{\prime}\left[\text { traD36, lacI }{ }^{\mathrm{q}} \text {, lacZ }\right. \\
\Delta \mathrm{M} 15]\end{array}$ & Yanisch-Perron et al. 1985 \\
\hline ED8767/pRK2073 & Helper strain, harboring pRK2073, recA met, $\mathrm{Spc}^{\mathrm{r}}$ & Murray et al. 1977 \\
\hline \multicolumn{3}{|c|}{1} \\
\hline pRK2073 & Helper plasmid, $\mathrm{Tra}^{+}, \mathrm{Mob}^{+}, \mathrm{ColE} 1, \mathrm{Spc}^{\mathrm{r}}$ & Leong et al. 1982 \\
\hline pPH1JI & $\mathrm{Tra}^{+}, \mathrm{Mob}^{+}$, IncP replicon, $\mathrm{Spc}^{\mathrm{r}}, \mathrm{Gm}^{\mathrm{r}}$ & Hirsch and Beringer 1984 \\
\hline pK $18 \mathrm{mob}$ & Suicide plasmid in X. campestris pv. campestris, $\operatorname{Kan}^{\mathrm{r}}$ & Schafer et al. 1994 \\
\hline pK3314 & pK18mob containing a 205-bp fragment of XC_3314 ORF, $\mathrm{Kan}^{\mathrm{r}}$ & This study \\
\hline pK3013 & pK18mob containing a 303-bp fragment of XC_3013 ORF, Kan ${ }^{\mathrm{r}}$ & This study \\
\hline pLAFR6 & Broad host range cloning vector, $\mathrm{RK} 2$ replicon, $\mathrm{Tra}^{-}, \mathrm{Mob}^{+}, \mathrm{Tc}^{\mathrm{r}}$ & Huynh et al. 1989 \\
\hline pXC3314 & pLAFR6 containing a 1,072-bp fragment including XC_3314 gene, $\mathrm{Tc}^{\mathrm{r}}$ & This study \\
\hline pLGUS0241 & pLAFR6 containing T3S signal of $x о p X c c N$ fused with promoterless gus gene, $\mathrm{Tc}^{\mathrm{r}}$ & Jiang et al. 2008 \\
\hline
\end{tabular}

${ }^{\mathrm{a}} \mathrm{Gm}^{\mathrm{r}}, \mathrm{Kan}^{\mathrm{r}}, \mathrm{Rif}^{\mathrm{r}}, \mathrm{Spc}^{\mathrm{r}}$, and $\mathrm{Tc}^{\mathrm{r}}=$ gentamicin, kanamycin, rifampicin, spectinomycin, and tetracycline resistant, respectively; HR = hypersensitive response; $\mathrm{ORF}=$ open reading frame. 
from the infected leaves was approximately 50-fold fewer than that of the wild-type strain 6 days postinoculation and onward (Fig. 3D). The growth capacity of the $d s b B$ mutant could be restored by $d s b B$ in trans (Fig. 3D). These results indicate that DsbB is required for in planta multiplication of $X$. campestris pv. campestris.

\section{DsbB is essential for full function of the type III secretion system of $X$. campestris pv. campestris.}

It has been well established that the type III secretion system (T3SS) is essential for HR induction of $X$. campestris (Büttner and Bonas 2006). Because mutation in the $d s b B$ gene of $X$. campestris pv. campestris resulted in loss of HR induction, it is probable that DsbB may be important for the T3SS of the pathogen. To validate this probability, we determined the functionality of the T3SS of the $d s b B$ mutant. The key function of the T3SS of pathogenic bacteria is to secrete effector proteins into host cells. Our recent work has demonstrated that the $x o p X c c N$ of $X$. campestris pv. campestris encodes a T3SS effector (Jiang et al. 2008). T3SS effectors generally have a modular structure, and targeting signal generally resides in the N-terminal 50 or 100 amino acids (Mudgett et al. 2000). A strategy of fusing such signal sequences with a $\beta$-glucuronidase (GUS) reporter has been successfully utilized to identify T3SS effectors from $X$. campestris pv. campestris (Jiang et al. 2008; Xu et al. 2008). In this work, we employed one of these recombinant reporter plasmids, pLGUS0241 (Table 1), to study the effect of mutation in the $d s b B$ gene on T3SS of $X$. campestris pv. campestris. The recombinant reporter plasmid pLGUS0241 was constructed by fusing the promoterless gus gene with a fragment including the promoter and secretion signal-encoding region (from the 488th bp upstream to the 159th bp downstream of the start codon) of $x o p X c c N$ (Jiang et al. 2008). Because the $d s b B$ mutant 077F07 and the $h r c V$ mutant 050B12 (defective in T3SS apparatus) (Table 1) were from Tn5gusA5 mutagenesis and harbored a gus-reporter gene already, we constructed new $d s b B$ and $h r c V$ mutants named $\Delta \mathrm{dsbB}$ and $\Delta \mathrm{hrcV}$, respectively, by the suicide plasmid pK18mob integration (details below). The reporter plasmid pLGUS0241 was introduced into the $d s b B$ mutant $\Delta \mathrm{dsbB}$, the $h r c V$ mutant $\Delta \mathrm{hrcV}$, and the wild-type 8004 by triparental conjugation. The obtained transconjugants $\Delta \mathrm{dsbB} /$ pLGUS0241, 8004/pLGUS0241, and $\Delta \mathrm{hrcV} / \mathrm{pLGUS0241}$ were subsequently analyzed for their GUS activities.

GUS activity in the supernatant of $\Delta \mathrm{dsbB} / \mathrm{pLGUS0241}$ was significantly lower than that of $8004 / \mathrm{pLGUS} 0241(P=0.01$ by $t$ test) (Fig. 4). However, after lysis of the bacterial cells in the cultures with methylphenol, the GUS activities of the strains $\Delta$ dsbB/pLGUS0241 and 8004/pLGUS0241 were not significantly different ( $P=0.05$ by $t$ test) (Fig. 4), suggesting that the GUS enzyme in $\Delta \mathrm{dsbB} / \mathrm{pLGUS} 0241$ was regularly expressed and the overwhelming majority of the enzyme remained inside the bacterial cells. $\Delta$ dsbB/pLGUS0241 still produced $28.6 \%$ GUS activity of the wild type in the supernatant before lysis of the cells, whereas the T3SS-structural mutant strain $\Delta$ hrcV/pLGUS0241 showed negligible GUS activity (Fig. 4). These results imply that, although mutation in $d s b B$ does not completely disable the T3SS, DsbB is essential for full function of the T3SS of $X$. campestris pv. campestris.

\section{DsbB is essential for effective type II secretion system of $X$. campestris pv. campestris.}

$X$. campestris pv. campestris produces extracellular polysaccharide (EPS) and extracellular enzymes that collectively contribute to pathogenesis (Dow and Daniels 1994). To investigate the role of DsbB in the production of these pathogenicity factors, we tested the production of extracellular enzymes (amylase and protease) and EPS of the $d s b B$ mutant. The results showed that there was no significant difference in EPS production between the $d s b B$ mutant strain 077F07 and the wild-type strain 8004 (data not shown), indicating that DsbB may not be involved in EPS production of $X$. campestris pv. campestris. However, like the T2SS-structural $x p s D$ mutant $285 \mathrm{D} 12$, the $d s b B$ mutant $077 \mathrm{~F} 07$ could not produce extracellular amylase and protease activities (Fig. 5). This deficient phenotype of the $d s b B$ mutant could be restored to wild-type level by $d s b B$ in trans (Fig. 5, complemented strain C077F07). Furthermore, after lysis of the bacterial cells with chloroform vapor, the amylase and protease activities of the $d s b B$ mutant could be almost fully restored to the wild-type level (Fig. 5). There are two amylase genes and six protease genes annotated in the X. campestris pv. campestris 8004 (Qian et al. 2005). The amy mutant strain 069G09 (a mutation in the major amylase-coding ORF XC_0141; GenBank accession number YP_241249) and the prt mutant strain 001F10 (a mutation in the major protease-coding ORF XC_3379; GenBank accession number YP_244443) showed negligible activity of amylase and protease, respectively, before or after lysis of the bacterial cells in the tested conditions (Fig. 5). These results suggest that there is a large amount of mature amylase and protease accumulated in the cells of the $d s b B$ mutant and the defect in the
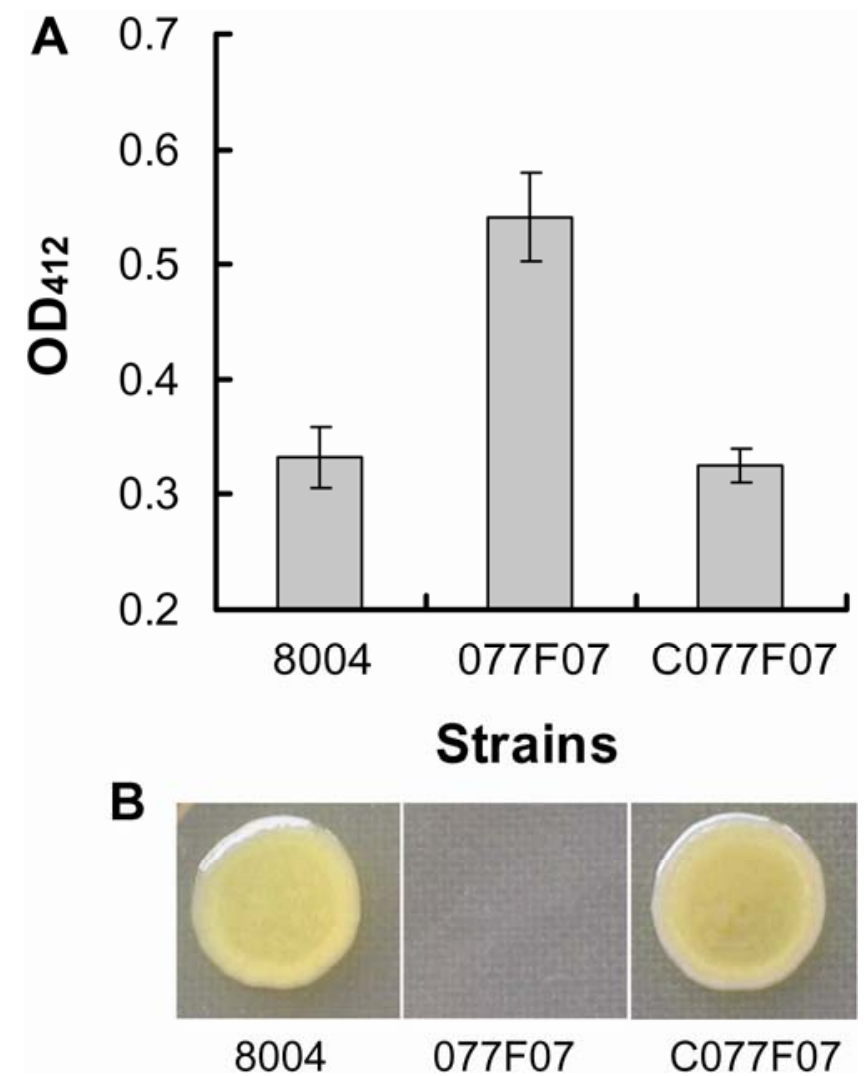

Fig. 2. Analysis of the periplasmic disulfide oxidoreductase activity of Xanthomonas campestris pv. campestris strains. A, Accumulation of proteins with reduced cysteines determined by the Ellman's reaction analysis. Value is the mean \pm standard deviation from three repeats; $\mathrm{OD}_{412}=$ optical density at $412 \mathrm{~nm}$. B, Dithiothreitol (DTT) sensitivity detection. Overnight culture $(2 \mu \mathrm{l})$ of each $X$. campestris pv. campestris strain was spotted onto NYGA (Daniels et al. 1984a) supplemented with DTT to a final concentration of $10 \mathrm{mM}$ and incubated at $28^{\circ} \mathrm{C}$. Photographs were taken 1 day after inoculation. Three plates were inoculated in each experiment and each experiment was repeated three times. Data presented were from representative plates and similar results were obtained in all plates of an experiment or in the plates of other independent experiments. 
extracellular enzyme activity of the $d s b B$ mutant is due to ineffectual type II secretion system (T2SS). Overall, these findings reveal that DsbB is essential for effective T2SS of $X$. campestris pv. campestris.

\section{DsbB is essential for the cell motility and}

flagellar assembly of $X$. campestris pv. campestris.

It has been demonstrated that DsbB is essential for cell motility of Escherichia coli (Dailey and Berg 1993). To verify whether mutation in the $d s b B$ gene of $X$. campestris pv. campestris affects cell motility, we examined the motility of the $d s b B$ mutant strain 077F07. The result showed that the radius of the growth zone resulting from cell motility of the mutant on the test plate was only approximately $0.4 \mathrm{~cm}$ while the radius of the wild type was approximately $1.0 \mathrm{~cm}$ (Fig. 6 ), indicating that disruption of the $X$. campestris pv. campestris $d s b B$ gene resulted in severe defects in cell motility of the pathogen. The radius of the complemented strain C077F07 was approximately $0.98 \mathrm{~cm}$ (Fig. 6), suggesting that the cell motility of the $d s b B$ mutant could be restored by $d s b B$ in trans. The bacterium in the Xanthomonas genus has a single polar flagellum (Starr 1981). To find out whether mutation in the $d s b B$ gene affects the bacterial flagellum biogenesis, we tested whether flagellum is produced by the $d s b B$ mutant strain 077F07. In the tested conditions (details below), approximately $10 \%$ of the cells of the wild-type strain 8004 and the complemented strain C077F07 always showed flagellum. However, no flagellum was observed from any of the mutant cells (Fig. 6). These findings reveal that DsbB is essential for the cell motility and flagellar assembly of $X$. campestris pv. campestris.

\section{DISCUSSION}

In this study, we have come to the conclusion that the ORF XC_3314 of $X$. campestris pv. campestris encodes a DsbB protein on the basis of the facts that the predicted XC3314 protein structurally possesses the DsbB's typical characteristics (i.e., amino acid sequence homology, a redox active Cys$\mathrm{X}$-X-Cys motif, and four times' spanning of the cytoplasmic membrane with both $\mathrm{N}$ and $\mathrm{C}$ termini facing the cytoplasm), and the finding that mutation in XC_3314 resulted in significant reduction of periplasmic disulfide oxidoreductase activity. In gram-negative bacteria, it has been established that two independent metabolic pathways are involved in disulfide bond formation in extracytoplasmic proteins. One is the DsbA/DsbB oxidation pathway and the other is the isomerization/reduction pathway (Collet and Bardwell 2002; Kadokura et al. 2003; Łasica and Jagusztyn-Krynicka 2007; Messens and Collet 2006; Nakamoto and Bardwell 2004). In silico genomic analysis and database sequence comparison showed that most bacterial species possess only one $d s b A$ and one $d s b B$ gene (Łasica and Jagusztyn-Krynicka 2007). We performed a database search and found that the genome of $X$. campestris pv. campestris 8004 has two dsbA gene homologs (XC_0764 [YP_241862] and XC_0765 [YP_241863]) and only one $d s b B$ homolog (i.e., XC_3314). No $d s b I$ (a $d s b B$ paralog) homolog was found in the strain 8004 (Qian et al. 2005). An attempt has

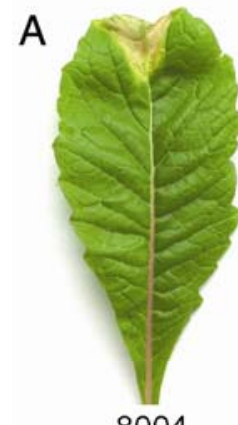

8004

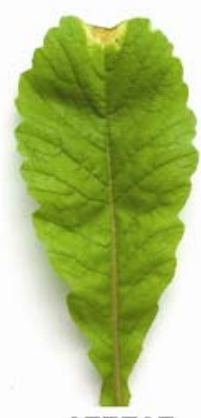

077F07

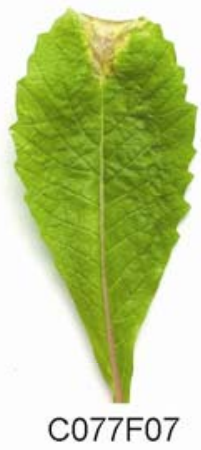

C077F07
C

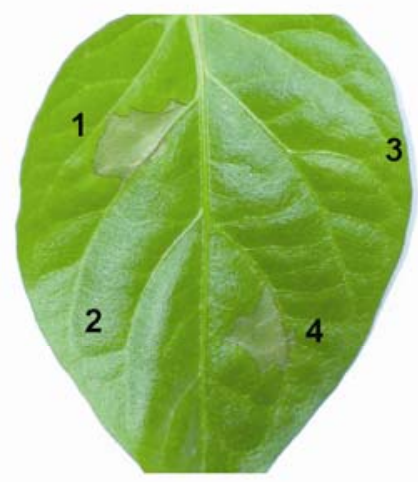

$\mathrm{D}$

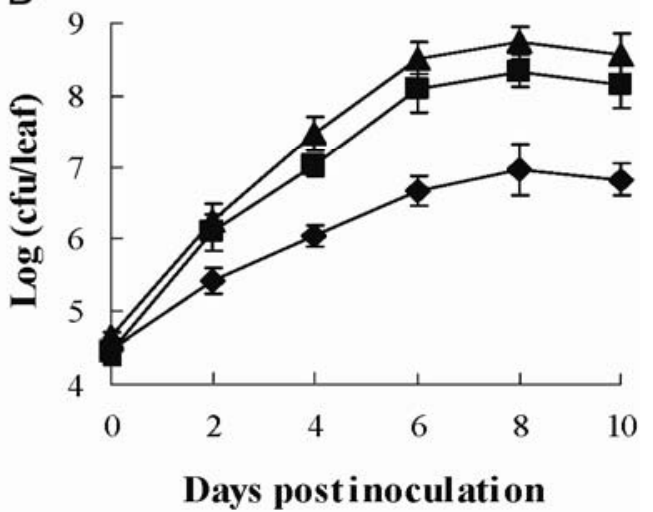

Fig. 3. DsbB is essential for full virulence, hypersensitive response (HR), and in planta growth of Xanthomonas campestris pv. campestris. A, Symptoms on Chinese radish leaves caused by $X$. campestris pv. campestris strains. Photographs were taken 10 days after inoculation. B, The average lesion lengths caused by $X$. campestris pv. campestris strains. Value is the mean \pm standard deviation (SD) from three repeats, each with 50 leaves. C, HR induced by $X$. campestris pv. campestris strains on pepper ECW-10R: 1, Wild-type strain 8004; 2, hrcV mutant 050B12; 3, dsbB mutant 077F07; 4, complemented strain C077F07. Photographs were taken 1 day after inoculation. D, Growth of $X$. campestris pv. campestris strains in Chinese radish leaves. Data are the mean \pm $\mathrm{SD}$ from three repeats; $\boldsymbol{\Delta}$ represents $8004, \diamond$ represents 077F07, and $\boldsymbol{\nabla}$ represents C077F07. 
been made to investigate the role of the $d s b A$ homologs in the pathogenesis process of $X$. campestris pv. campestris in our laboratory. However, mutation in any one of the two $d s b A$ gene homologs did not affect the virulence or HR of the pathogen (unpublished data). Construction of a mutant with double mutations in the $d s b A$ homologs for further verification of their role in pathogenicity and disulfide bond formation is under way. For the isomerization/reduction pathway in $X$. campestris pv. campestris, one $d s b C$ homolog (XC_3579 [YP_244641]) and one $d s b D$ homolog (XC_0531 [YP_241632]) were annotated (Qian et al. 2005). Mutants of the putative $d s b C$ and $d s b D$ genes showed reduced virulence (our unpublished data). Two $d s b E$ homologs (XC_1892 [YP_242975] and XC_2573 [YP_243643]) were annotated (Qian et al. 2005) and mutation in any one of them did not affect virulence (unpublished data). No $d s b G$ homolog is present in the $X$. campestris pv. campestris 8004 (Qian et al. 2005).

HR is a typically incompatible phenomenon stimulated by a pathogenic bacterium harboring an avirulence $(a v r)$ gene on a host or nonhost plant that carries a cognate resistance $(R)$ gene (Jones and Dangl 2006). Our previous work revealed that the HR elicited on the pepper cv. ECW-10R by X. campestris pv. campestris 8004 is due to the involvement of the resistance gene $B s 1$ in the plant and the cognate $a v r$ gene $a v r B s l$ in the patho-

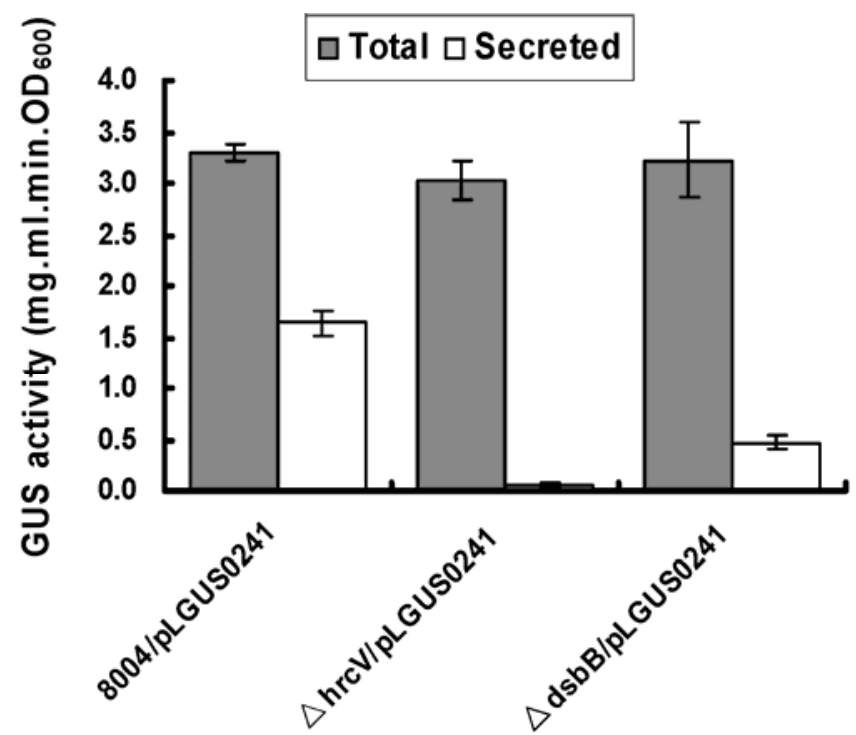

Fig. 4. DsbB is essential for effective type III secretion system of Xanthomonas campestris pv. campestris. The $\beta$-glucuronidase (GUS) activities in the cultural supernatant (Secreted) and the supernatant of methylphenol treated culture (Total) were determined after growth of $X$. campestris $\mathrm{pv}$. campestris strains in MME medium (Ryan et al. 2007) for $24 \mathrm{~h}$. Value is the mean \pm standard deviation from three repeats. gen (Xu et al. 2008). It has been well established that a number of hypersensitive response and pathogenicity ( $h r p)$ and $h r p$ conserved $(h r c)$ genes in bacterial pathogens are involved in HR production and most of the hrp and hrc genes encode components of the T3SS that translocates effector proteins (such as Avr proteins) directly into the plant cells (Büttner and Bonas 2006; Cornelis 2006; Lindgren 1997). Inactivation of a pathogen's T3SS will lead the pathogen to lose the capability to translocate effectors into plant cells; thus, the pathogen is unable to elicit HR. The findings that the $d s b B$ mutant strain $\Delta \mathrm{dsbB}$ harboring the GUS translocation reporter plasmid pLGUS0241 produced significantly lower secreted GUS activity than the wild type carrying the same plasmid, and that lysis of the mutant cells restored the GUS activity to wild-type level (Fig. 4), suggest that mutation in $d s b B$ affects the translocation function of the pathogen's T3SS. A model for the role of $X$. campestris pv. vescatoria Hrp or Hrc proteins in T3SS has been proposed, in which most Hrc proteins (HrcC, HrcJ, HrcR, HrcS, HrcT, HrcU, and HrcV) form the core of the T3SS apparatus that crosses the bacterial cell membrane (Büttner and Bonas 2006; Rossier et al. 2000). All of these Hrc proteins are conserved in the $X$. campestris pv. campestris 8004 (Qian et al. 2005). Among these X. campestris pv. campestris Hrc proteins, HrcJ (XC_3009 [YP_244077]), HrcR (XC_3016 [YP_244084]), HrcU (XC_3012 [YP_ 244080]), and HrcV (XC_3013 [YP_244081]) contain two or three cysteine residues, respectively, although $\mathrm{HrcC}$ (XC_3003 [YP_244071]) and HrcS (XC_3017 [YP_244085]) contains only one cysteine residue. Transmembrane helices analysis

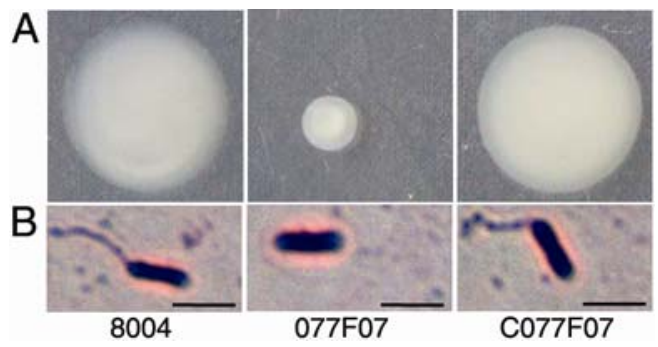

Fig. 6. DsbB is essential for cell motility and flagellar assembly of Xanthomonas campestris pv. campestris. A, Cell motility on plates. Overnight culture $(2 \mu \mathrm{l})$ of each strain with optical density of 1.0 at $600 \mathrm{~nm}$ was stabbed into the XOLN (Fu and Tseng 1990) agar (0.3\%, wt/vol) plates and incubated for 4 days at $28^{\circ} \mathrm{C}$ as described by Lee and associates (2003). Photographs were taken 4 days after inoculation. B, Bacterial electron micrograph. Bacterial cells were grown on NYGA medium at $28^{\circ} \mathrm{C}$ for $24 \mathrm{~h}$, stained with $1 \%$ carbol fuchsin, and observed with electron microscope (Hitachi model H-500) at an accelerating voltage of $80 \mathrm{kV}$. Approximately $10 \%$ of the cells of the wild-type strain 8004 and the complemented strain C077F07 showed flagellum, whereas no flagellum was observed from any of the mutant cells. The experiment was repeated twice and similar results were obtained. Bar $=1 \mu \mathrm{m}$.
A

A $8004 \quad 077 F 07 \quad$ C077F07 285D12 001F10

a

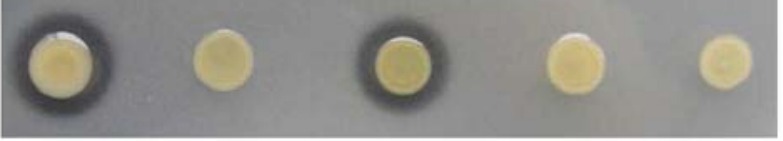

b

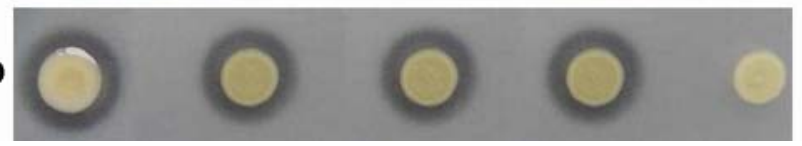

B

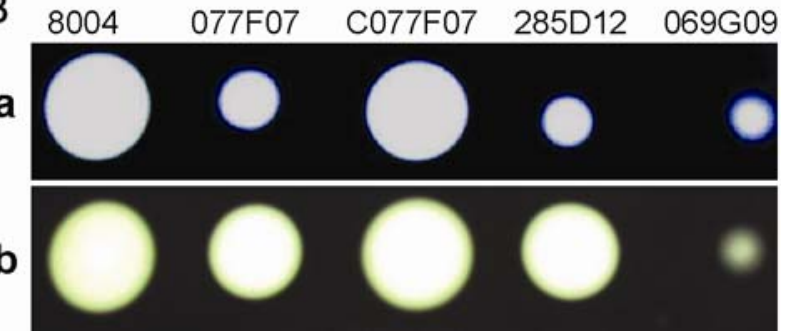

Fig. 5. DsbB is essential for effective type II secretion system of Xanthomonas campestris pv. campestris. Overnight culture (2 $\mu$ l) was spotted onto NYGA plates containing A, $0.5 \%$ (wt/vol) skimmed milk (for protease) or $\mathbf{B}, 0.1 \%$ (wt/vol) starch (for amylase). After incubation at $28^{\circ} \mathrm{C}$ for $24 \mathrm{~h}$, plates were a, stained when necessary and photographed or b, treated with chloroform vapor and incubated at $28^{\circ} \mathrm{C}$ for another $24 \mathrm{~h}$ before being stained and photographed. Three plates were inoculated in each experiment and each experiment was repeated three times. Data presented were from representative plates and similar results were obtained in all plates of an experiment or in the plates of other independent experiments. 
showed that at least one cysteine residue of $\mathrm{HrcJ}$, HrcR, HrcU, and $\mathrm{HrcV}$ proteins is located in the periplasmic region. It is possible that $\mathrm{HrcJ}, \mathrm{HrcR}, \mathrm{HrcU}$, and $\mathrm{HrcV}$ proteins may form disulfide bonds via the DsbA/DsbB pathway in periplasm to remain their structural stability. Interestingly, many other $X$. campestris pv. campestris Hrp proteins (HrpB1, HrpB4, HrpF, and $\mathrm{HrpW}$ ) contain four to nine cysteine residues (Qian et al. 2005). To investigate whether these proteins need to form disulfide bonds for their function will be valuable.

It has been demonstrated that gram-negative bacterial pathogens secrete many important virulence factors, including extracellular enzymes via T2SS (Cianciotto 2005; Johnson et al. 2006). The components of T2SS are located in inner and outer membranes where they assemble into a multiprotein, cell-envelope spanning, complex (Cianciotto 2005; Johnson et al. 2006). In $X$. campestris pv. campestris, among the T2SS components, XpsD (XC_3563 [YP_244626]), XpsM (XC_3565 [YP_244628]), and XcsN (XC_0749 [YP_241847]) proteins possess two to three cysteine residues (Qian et al. 2005). According to the proposed model of the T2SS apparatus (Filloux 2004; Johnson et al. 2006; Sandkvist 2001), XpsD, $\mathrm{XpsM}$, and $\mathrm{XcsN}$ are outer and inner membrane proteins and periplasmic protein, respectively, which are the main proteins forming the secretion pore across the inner and outer membranes. Transmembrane helice analysis showed that the cysteine residues of these proteins are located in periplasmic region. It is possible that, in $X$. campestris pv. campestris, these proteins need to form disulfide bonds via the DsbA/DsbB pathway in periplasm before being assembled into the T2SS apparatus.

It was found that the $d s b B$ mutant of $E$. coli failed to assemble functional flagella (Dailey and Berg 1993). In E. coli, the FlgI protein, which possesses one disulfide bridge, is the component of the flagellar P ring (Easica and Jagusztyn-Krynicka 2007; Pallen et al. 2005). It has been shown that the intramolecular disulfide bond formation in FlgI is important to prevent the degradation of the FlgI protein, although it is not absolutely required for $\mathrm{P}$ ring assembly (Hizukuri et al. 2006). The predicted FlgI protein (XC_2241 [YP_243316]) of X. campestris pv. campestris contains only one cysteine residue (Qian et al. 2005), indicating that it does not form an intramolecular disulfide bond. However, the predicted FlgH protein (XC_2240 [YP_243315]) of $X$. campestris pv. campestris, which is the component of the flagellar L ring in the outer membrane, contains three cysteine residues (Qian et al. 2005). In X. campestris pv. campestris, whether the DsbA/DsbB pathway affects motility and flagellar assembly via the intramolecular disulfide bond formation of the $\mathrm{FlgH}$ protein remains to be further verified.

In addition to a direct effect on the disulfide bond formation of some constituents of T2SS, T3SS, and flagellar apparatuses, the DsbA/DsbB pathway of $X$. campestris pv. campestris may affect the pathogenesis process by other mechanisms. In Salmonella enterica, DsbA is involved in Salmonella pathogenicity island 1 (SPI1) T3SS function. Loss of DsbA independently affects SPI1 regulation and SPI1 function. Recently, it has been shown that the $d s b A$-mediated feedback inhibition of SPI1 transcription is not due to defects in the SPI1 T3SS apparatus. Rather, the SPI1 T3SS responds to the disulfide bond status of the periplasm through the RcsCDB phosphorelay system and the flagellar system (Lin et al. 2008). More studies are required to fully clarify the molecular mechanisms by which DsbB influences the pathogenesis of $X$. campestris pv. campestris.

\section{MATERIALS AND METHODS}

\section{Bacterial strains, plasmids, and growth conditions.}

The bacterial strains and plasmids used in this work are listed in Table 1. E. coli cells were grown in Luria-Bertani
(LB) broth or on LB agar medium (Miller 1972) at $37^{\circ} \mathrm{C} . X$. campestris pv. campestris strains were cultivated at $28^{\circ} \mathrm{C}$ in NYGB, on NYG agar medium (NYGA) (Daniels et al. 1984a), in MMX medium (Daniels et al. 1984b), or in the hrp-inducing MME medium (Ryan et al. 2007). Antibiotics were used at the following final concentrations: gentamicin $(\mathrm{Gm}), 5 \mu \mathrm{g} / \mathrm{ml}$; kanamycin (Kan), $25 \mu \mathrm{g} / \mathrm{ml}$; rifampicin (Rif), $50 \mu \mathrm{g} / \mathrm{ml}$; spectinomycin (Spc), $50 \mu \mathrm{g} / \mathrm{ml}$; and tetracycline (Tc), $15 \mu \mathrm{g} / \mathrm{ml}$ for E. coli and $5 \mu \mathrm{g} / \mathrm{ml}$ for $X$. campestris pv. campestris.

\section{DNA manipulations.}

Standard DNA manipulations were carried out as described by Sambrook and associates (1989). Enzymes were supplied by Promega (Shanghai, China) and used in accordance with the manufacturer's instructions. The conjugation between $X$. campestris pv. campestris and $E$. coli strains using ED8767/pRK2073 as the helper was performed as described by Turner and associates (1985).

\section{Mutant construction and complementation.}

The Tn5gusA5 insertional mutant of $d s b B$ (XC_3314) named 077F07, the T2SS-structural xpsD (XC_3563) mutant 285D12, the major protease mutant $001 \mathrm{~F} 10$, and the major amylase mutant 069G09 were from the insertional mutant library of the $X$. campestris pv. campestris 8004 in the authors' laboratory. The mutants were selected by mating the $X$. campestris pv. campestris 8004/pLAFR1::Tn5gusA5 with 8005/pPH1JI (Turner et al. 1985) (the plasmids pPH1JI and pLAFR1 are incompatible) and by plating them on the NYGA selection medium containing Rif (for 8004), Kan (for Tn5gusA5), and Gm and Spc (for pPH1JI). The Rif-Kan-Gm-Spc-resistant but Tc-sensitive individual transconjugants were chosen as candidate mutants. The genomic positions of the transposon in the mutants were determined by thermal asymmetric interlaced polymerase chain reaction (TAIL-PCR) (Liu and Huang 1998) and subsequent sequencing for comparison with the whole genome sequence of strain 8004 (Qian et al. 2005). The insertional site of Tn5gusA5 was further confirmed by PCR using the primers on transposon and on the gene upstream or downstream of the gene disrupted. The Tn5gusA5 transposon in the mutant 077F07 was located at the 452nd bp downstream of the start codon of the ORF XC_3314 $(d s b B)$ (Fig. 1).

To generate an integration mutant of $d s b B$, a 223-bp fragment including the region from the 14th to 218th bp downstream of the start codon of XC_3314 was amplified by PCR using the total DNA of the wild-type strain 8004 as the template and the primer set XC3314-F/XC3314-R (ggggaattcg ttggggtttcgggcgcaattc/gggggatcccatacgccttgcgcccaccgg), and cloned into the suicide plasmid pK18mob (Schafer et al. 1994), yielding the recombinant plasmid pK3314 (Table 1). After confirmation by sequencing, the plasmid pK3314 was transferred into the wild-type strain 8004 by triparental conjugation. Kan-resistant transconjugants were selected and further confirmed by PCR. One of the confirmed transconjugants was randomly chosen and designated as $\triangle \mathrm{dsbB}$ for further study.

For complementation of the mutation in $d s b B$ gene, a 1,072bp DNA fragment that includes the region from the 514th bp upstream of the start codon to the 29th bp downstream of the stop codon of XC_3314 (Fig. 1) was amplified by PCR using the primer set CdsbB-F/CdsbB-R (ggggaattcgaggtgtgtgctggcttgcatg cg/gggtctagaatcgcagacgceggcegcagcc) and the total DNA of strain 8004 as template. After confirmation by sequencing, the amplified DNA fragment was cloned into pLAFR6 (Huynh et al. 1989) to generate the recombinant plasmid pXC3314 (Table 1). The recombinant plasmid was then transferred into the $d s b B$ mutant $077 \mathrm{~F} 07$ by triparental conjugation. The transconjugants carrying pXC3314 were screened on NYGA supplemented with 
Rif, Kan, and Tc. A confirmed transconjugant representative was named C077F07 (Table 1) and was chosen for further study. For controls, the vector pLAFR6 was introduced into the wild-type 8004 and mutant $077 \mathrm{~F} 07$ by triparental conjugation.

To construct an integration mutant of $h r c V$, a 303-bp fragment containing the region from the 26th to 328th bp downstream of the start codon of the $h r c V$-encoded ORF XC_3013 (YP_244081) was amplified by PCR using the total DNA of the wild-type strain 8004 as the template and the primer set XC3013-F/XC3013-R (ggggaattcacaccggtgaagtggcgatcgc/ggg ggatccccagattgccgcccaccaccag), and cloned into the suicide plasmid pK18mob, yielding the recombinant plasmid pK3013 (Table 1). After confirmation by sequencing, the plasmid pK3013 was transferred into the wild-type strain 8004 by triparental conjugation. Kan-resistant transconjugants were selected and further confirmed by PCR. One of the confirmed transconjugants was randomly chosen and was designated as $\Delta \mathrm{hrcV}$ for further study.

\section{Ellman's assay.}

Accumulation of periplasmic proteins with reduced cysteines was determined by the Ellman's reaction (Riddles et al. 1979). Periplasmic protein samples from bacterial cells were isolated by the chloroform method with a small modification (Ames et al. 1984). In the final step, $10 \mathrm{mM}$ Tris (pH 8.0) was replaced by the Ellman's buffer $(50 \mathrm{mM}$ phosphate buffer, $\mathrm{pH}$ 7.5 , containing $1 \mathrm{mM}$ EDTA and $1 \mathrm{mM}$ phenylmethanesulfonyl fluoride) (Ames et al. 1984). The X. campestris pv. campestris wild-type strain 8004 and the $d s b B$ mutant strain 077F07 were grown in NYGB at $28^{\circ} \mathrm{C}$ with shaking at 200 rpm for $16 \mathrm{~h}$. Cell concentration was adjusted into an optical density of 0.5 at $600 \mathrm{~nm}\left(\mathrm{OD}_{600}=0.5\right)$. Bacterial cultures $(2 \mathrm{ml}$ each) were collected and treated with chloroform. The Ellman's reagent $\left(5,5^{\prime}\right.$-dithiobis [2-nitrobenzoic acid]) at a final concentration of $0.8 \mathrm{mM}$ was added to each supernatant sample containing periplasmic proteins. The absorbance at $412 \mathrm{~nm}$ was determined after $1 \mathrm{~min}$ of incubation at room temperature. The assays were carried out in three independent experiments.

\section{DTT sensitivity tests.}

For the DTT sensitivity test, $2 \mu \mathrm{l}$ of overnight culture of each $X$. campestris pv. campestris strain $\mathrm{OD}_{600}=1.0$ was spotted onto NYGA supplemented with DTT to a final concentration of $10 \mathrm{mM}$ and incubated at $28^{\circ} \mathrm{C}$ for $48 \mathrm{~h}$. At least three plates were inoculated in each experiment and each experiment was repeated three times.

\section{Motility assay.}

For cell motility assay, $2 \mu \mathrm{l}$ of overnight culture of each $X$. campestris pv. campestris strain with $\mathrm{OD}_{600}=1.0$ was stabbed into the XOLN agar $(0.3 \%, \mathrm{wt} / \mathrm{vol})$ plates and incubated for 4 days at $28^{\circ} \mathrm{C}$ as described by Lee and associates (2003). $\mathrm{XOLN}$ is the basal salt medium containing $0.0625 \%$ yeast extract and $0.0625 \%$ tryptone (Fu and Tseng 1990).

\section{Flagella observation.}

For observation of flagella, X. campestris pv. campestris strains were grown on NYGA medium at $28^{\circ} \mathrm{C}$ for $24 \mathrm{~h}$. The bacterial cells were then stained with $1 \%$ carbol fuchsin (basic fuchsin, $5 \mathrm{~g}$; methanol, $50 \mathrm{ml}$; phenol, $25 \mathrm{ml}$; and water, 500 $\mathrm{ml}$ ) and observed with electron microscope (Hitachi model $\mathrm{H}-$ 500) at an accelerating voltage of $80 \mathrm{kV}$.

\section{Test of extracellular enzyme activity} and exopolysaccharide production.

A radial diffusion assay (Tang et al. 1987) was used to test the activity of extracellular amylase and protease. An over- night culture $\left(2 \mu \mathrm{l}, \mathrm{OD}_{600}=1.0\right)$ of each $X$. campestris pv. campestris strain was spotted onto a NYGA plate containing $0.1 \%$ (wt/vol) starch (for amylase) (Sangon, Shanghai, China) or $0.5 \%$ (wt/vol) skimmed milk (for protease) (Sangon) respectively, and was incubated at $28^{\circ} \mathrm{C}$ for $24 \mathrm{~h}$. Plates were stained when necessary, as described by Tang and associates (1991). Zones of clearance around the spot due to the degradation of the substrate were photographed. At least three plates were inoculated in each experiment and each experiment was repeated three times. The relative activity of the enzyme was indicated by the diameter of the clear zone. To detect the intracellular enzyme activity, the bacterial cells on the test plates were treated with chloroform vapor as described by Tang and associates (1987).

To determine EPS production, $X$. campestris pv. campestris strains were cultured in $100 \mathrm{ml}$ of NYGB containing $2 \%$ (wt/vol) glucose at $28^{\circ} \mathrm{C}$ with shaking at $200 \mathrm{rpm}$ for 3 days. EPS was precipitated from the culture supernatant with ethanol, dried, and weighed as described by Tang and associates (1991).

\section{Determination of GUS activity.}

$X$. campestris pv. campestris strains were cultured in MME medium for $24 \mathrm{~h}$. To determine the GUS activity of secreted proteins, the bacterial cells of $200 \mu \mathrm{l}$ of culture for each strain was separated by centrifugation and the cell-free supernatant was taken for GUS activity determination. For determination of the total GUS activity, $200 \mu \mathrm{l}$ of culture for each strain was mixed with $40 \mu \mathrm{l}$ of methylphenol and vortexed. The supernatant was then taken for GUS activity assay. The GUS activity assay was performed by measurement of the $\mathrm{OD}_{415}$ using $\rho$ nitrophenyl- $\beta$-D-glucuronide as substrate as described by Jefferson and associates (1986).

\section{Plant assay.}

To test the virulence of $X$. campestris pv. campestris, strains were inoculated on Chinese radish manshenhong (Raphanus sativus L. var. radiculus Pers.) by a leaf clipping method as described by Dow and associates (2003). X. campestris pv. campestris strains were grown overnight at $28^{\circ} \mathrm{C}$ with shaking at $200 \mathrm{rpm}$ in NYGB medium. Five-week-old Chinese radish seedlings were inoculated by clipping vein endings of the last completely expanded leaf with sterilized scissors dipped in bacterial cultures which were resuspended in sterile water to an $\mathrm{OD}_{600}$ of 0.001. After inoculation, the plants were placed in a greenhouse with temperatures of 25 to $30^{\circ} \mathrm{C}$ and relative humidity above $90 \%$. Lesion length of more than 50 leaves was scored at 10 days after inoculation. Experiments were repeated independently three times.

To investigate the growth of bacteria in planta, 5-week-old Chinese radish seedlings were inoculated by the same method used for virulence determination as described above, and five inoculated leaves for each sampling were homogenized in $9 \mathrm{ml}$ of sterilized water. Diluted homogenates were plated on NYGA medium supplemented with appropriate antibiotics. Bacterial CFU were counted after incubation at $28^{\circ} \mathrm{C}$ for 3 days.

HR was tested on the pepper cv. ECW-10R (Capsicum annuum cv. ECW-10R) carrying the resistance gene Bsl (Minsavage et al. 1990), which is one of the nonhosts commonly used to test the HR of $X$. campestris pv. campestris (Newman et al. 2001; Xu et al. 2008). The pepper leaves were inoculated by infiltrating approximately $5 \mu$ of bacterial suspension $\left(10^{8} \mathrm{CFU} / \mathrm{ml}\right)$ in $10 \mathrm{mM}$ sodium phosphate buffer $(5.8$ $\mathrm{mM} \mathrm{Na}_{2} \mathrm{HPO}_{4}$ and $4.2 \mathrm{mM} \mathrm{NaH} \mathrm{PO}_{4}, \mathrm{pH} 7.0$ ) into the abaxial leaf surface using a blunt-end plastic syringe. After inoculation, the plants were kept at $28^{\circ} \mathrm{C}$ under continuous illumina- 
tion of 6,000 lux light intensity for at least $6 \mathrm{~h}$. At least three plants were inoculated in each experiment and each experiment was repeated at least twice.

\section{Bioinformatics analyses.}

The amino acid sequences of $X$. campestris pv. campestris and $P$. aeruginosa PAO1 DsbB proteins were from the database of the National Center for Biotechnology Information (NCBI). Prediction of transmembrane helices in proteins was performed with TMHMM Server v. 2.0 software (Krogh et al. 2001).

\section{ACKNOWLEDGMENTS}

We thank M. Arlat for providing pepper seed. This work was supported by the ' 863 ' Program of the Ministry of Science and Technology of China (2006AA02Z175 and 2006AA10Z185) and the National Science Foundation of China (30470020 and 30730004).

\section{LITERATURE CITED}

Agudo, D., Mendoza, M. T., Castanares, C., Nombela, C., and Rotger, R. 2004. A proteomic approach to study Salmonella typhi periplasmic proteins altered by a lack of the DsbA thiol: Disulfide isomerase. Proteomics 4:355-363.

Altmeyer, R. M., McNern, J. K., Bossio, J. C., Rosenshine, I., Finlay, B. B., and Galán, J. E. 1993. Cloning and molecular characterization of a gene involved in Salmonella adherence and invasion of cultured epithelial cells. Mol. Microbiol. 7:89-98.

Alvarez, A. M. 2000. Black rot of crucifers. Pages 21-52 in: Mechanisms of Resistance to Plant Diseases. A. J. Slusarenko, R. S. S. Fraser, and L.C. van Loon, eds. Kluwer Academic Publishers, Dordrecht, The Netherlands.

Ames, G. F., Prody, C., and Kutsu, S. 1984. Simple, rapid, and quantitative release of periplasmic proteins by chloroform. J. Bacteriol. 160:1181-1183.

Bouwman, C. W., Kohli, M., Killoran, A., Touchie, G. A., Kadner, R. J., and Martin, N. L. 2003. Characterization of SrgA, a Salmonella enterica serovar Typhimurium virulence plasmid-encoded paralogue of the disulfide oxidoreductase DsbA, essential for biogenesis of plasmidencoded fimbriae. J. Bacteriol. 185:991-1000.

Braun, P., Ockhuijsen, C., Eppens, E., Koster, M., Bitter, W., and Tommassen, J. 2001. Maturation of Pseudomonas aeruginosa elastase. Formation of the disulfide bonds. J. Biol. Chem. 276:26030-26035.

Büttner, D., and Bonas, U. 2006. Who comes first? How plant pathogenic bacteria orchestrate type III secretion. Curr. Opin. Microbiol. 9:193200.

Cianciotto, N. P. 2005. Type II secretion: A protein secretion system for all seasons. Trends Microbiol. 13:581-588.

Collet, J. F., and Bardwell, J. C. 2002. Oxidative protein folding in bacteria. Mol. Microbiol. 44:1-8.

Cornelis, G. R. 2006. The type III secretion injectisome. Nat. Rev. Microbiol. 4:811-825.

Dailey, F. E., and Berg, H. C. 1993. Mutants in disulfide bond formation that disrupt flagellar assembly in Escherichia coli. Proc. Natl. Acad. Sci. U.S.A. 90:1043-1047.

Daniels, M. J., Barber, C. E., Turner, P. C., Cleary, W. G., and Sawczyc, M. K. 1984a. Isolation of mutants of Xanthomonas campestris pathovar campestris showing altered pathogenicity. J. Gen. Microbiol. 130:24472455.

Daniels, M. J., Barber, C. E., Turner, P. C., Sawczyc, M. K., Byrde, R. J. W., and Fielding, A. H. 1984b. Cloning of genes involved in pathogenicity of Xanthomonas campestris pv. campestris using the broad host range cosmid pLAFR1. EMBO (Eur. Mol. Biol. Organ.) J. 3:33233328.

Dow, J. M., and Daniels, M. J. 1994. Pathogenicity determinants and global regulation of pathogenicity of Xanthomonas campestris pv. campestris. Curr. Top. Microbiol. Immunol. 192:29-41.

Dow, J. M., Crossman, L., Findlay, K., He, Y. Q., Feng, J. X., and Tang, J. L. 2003. Biofilm dispersal in Xanthomonas campestris is controlled by cell-cell signaling and is required for full virulence to plants. Proc. Natl. Acad. Sci. U.S.A. 100:10995-11000.

Fabianek, R. A., Hennecke, H., and Thony-Meyer, L. 2000. Periplasmic protein thiol:disulfide oxidoreductases of Escherichia coli. FEMS (Fed. Eur. Microbiol. Soc.) Microbiol. Rev. 24:303-316.

Filloux, A. 2004. The underlying mechanisms of type II protein secretion.
Biochim. Biophys. Acta 1694:163-179.

Fu, J. F., and Tseng, Y. H. 1990. Construction of lactose-utilizing Xanthomonas campestris and production of xanthan gum from whey. Appl. Environ. Microbiol. 56:919-923.

Ha, U. H., Wang, Y., and Jin, S. 2003. DsbA of Pseudomonas aeruginosa is essential for multiple virulence factors. Infect. Immun. 71:15901595 .

Hardy, S. J., and Hedges, P. A. 1996. Reduced B subunit of heat-labile enterotoxin associates with membranes in vivo. Eur. J. Biochem. 236:412418.

Hiniker, A., and Bardwell, J. C. 2004. In vivo substrate specificity of periplasmic disulfide oxidoreductases. J. Biol. Chem. 279:1296712973.

Hirsch, P. R., and Beringer, J. E. 1984. A physical map of pPH1JI and pJB4JI. Plasmid 12:139-141.

Hizukuri, Y., Yakushi, T., Kawagishi, I., and Homma, M. 2006. Role of the intramolecular disulfide bond in FlgI, the flagellar P-ring component of Escherichia coli. J. Bacteriol. 188:4190-4197.

Huynh, T. V., Dahlbeck, D., and Staskawicz, B. J. 1989. Bacterial blight of soybean: Regulation of a pathogen gene determining host cultivar specificity. Science 245:1374-1377.

Jackson, M. W., and Plano, G. V. 1999. DsbA is required for stable expression of outer membrane protein YscC and for efficient Yop secretion in Yersinia pestis. J. Bacteriol. 181:5126-5130.

Jander, G., Martin, N. L., and Beckwith, J. 1994. Two cysteines in each periplasmic domain of the membrane protein DsbB are required for its function in protein disulfide bond formation. EMBO (Eur. Mol. Biol. Organ.) J. 13:5121-5127.

Jefferson, R. A., Burges, S. M., and Hirsh, D. 1986. $\beta$-Glucuronidase from Escherichia coli as a gene-fusion marker. Proc. Natl. Acad. Sci. U.S.A. 83:8447-8451

Jiang, B. L., He, Y. Q., Cen, W. J., Wei, H. Y., Jiang, G. F., Jiang, W., Hang, X. H., Feng, J. X., Lu, G. T., Tang, D. J., and Tang, J. L. 2008 The type III secretion effector XopXccN of Xanthomonas campestris pv. campestris is required for full virulence. Res. Microbiol. 159:216220.

Johnson, T. L., Abendroth, J., Hol, W. G. J., and Sandkvist, M. 2006. Type II secretion: From structure to function. FEMS (Fed. Eur. Microbiol. Soc.) Microbiol. Lett. 255:175-186.

Jones, J. D., and Dangl, J. L. 2006. The plant immune system. Nature 444:323-329.

Kadokura, H., Katzen, F., and Beckwith, J. 2003. Protein disulfide bond formation in prokaryotes. Annu. Rev. Biochem. 72:111-135.

Krogh, A., Larsson, B., von Heijne, G., and Sonnhammer, E. L. 2001. Predicting transmembrane protein topology with a hidden Markov model: Application to complete genomes. J. Mol. Biol. 305:567-580.

Łasica, A. M., and Jagusztyn-Krynicka, E. K. 2007. The role of Dsb proteins of gram-negative bacteria in the process of pathogenesis. FEMS (Fed. Eur. Microbiol. Soc.) Microbiol. Rev. 31:626-636.

Lee, M. C, Weng, S. F., and Tseng, Y. H. 2003. Flagellin gene fliC of Xanthomonas campestris is upregulated by transcription factor Clp. Biochem. Biophys. Res. Commun. 307:647-652.

Leong, S. A., Ditta, G. S., and Helinski, D. R. 1982. Heme biosynthesis in Rhizobium. Identification of a cloned gene coding for delta-aminolevulinic acid synthetase from Rhizobium meliloti. J. Biol. Chem. 257:87248730

Lin, D., Rao, C. V., and Slauch, J. M. 2008. The Salmonella SPI1 type three secretion system responds to periplasmic disulfide bond status via the flagellar apparatus and the RcsCDB system. J. Bacteriol. 190:87-97.

Lindgren, P. B. 1997. The role of hrp genes during plant-bacterial interactions. Annu. Rev. Phytopathol. 35:129-152.

Liu, Y. G., and Huang, N. 1998. Efficient amplification of insert end sequences from bacterial artificial chromosome clones by thermal asymmetric interlaced PCR. Plant Mol. Biol. Rep. 16:175-181.

Messens, J., and Collet, J. F. 2006. Pathways of disulfide bond formation in Escherichia coli. Int. J. Biochem. Cell Biol. 38:1050-1062.

Miki, T., Okada, N., and Danbara, H. 2004. Two periplasmic disulfide oxidoreductases, DsbA and SrgA, target outer membrane protein SpiA, a component of the Salmonella pathogenicity island 2 type III secretion system. J. Biol. Chem. 279:34631-34642.

Miller, J. H. 1972. Experiments in Molecular Genetics. Cold Spring Harbor Laboratory Press, Cold Spring Harbor, NY, U.S.A.

Minsavage, G. V., Dahlbeck, D., Whalen, M. C., Kearny, B., Bonas, U., Staskawicz, B. J., and Stall, R. E. 1990. Gene-for-gene relationships specifying disease resistance in Xanthomonas campestris pv. vesicatoria-pepper interactions. Mol. Plant-Microbe Interact. 3:41-47.

Missiakas, D., Georgopoulos, C., and Raina, S. 1993. Identification and characterization of the Escherichia coli gene $d s b B$, whose product is involved in the formation of disulfide bonds in vivo. Proc. Natl. Acad. Sci. U.S.A. 90:7084-7088. 
Mudgett, M. B., Chesnokova, O., Dahlbeck, D., Clark, E. T., Bonas, U., and Staskawicz, B. J. 2000. Molecular signals required for type III secretion and translocation of the Xanthomonas campestris AvrBs2 protein to pepper plants. Proc. Natl. Acad. Sci. U.S.A. 97:13324-13329.

Murray, N. E., Brammar, W. J., and Murray, K. 1977. Lambdoid phages that simplify the recovery of in vitro recombinants. Mol. Gen. Genet. 150:53-61.

Nakamoto, H., and Bardwell, J. C. 2004. Catalysis of disulfide bond formation and isomerization in the Escherichia coli periplasm. Biochim. Biophys. Acta 1694:111-119.

Newman, M. A., von Roepenack-Lahaye, E., Parr, A., Daniels, M. J., and Dow, J. M. 2001. Induction of hydroxycinnamoyl-tyramine conjugates in pepper by Xanthomonas campestris, a plant defense response activated by $h r p$ gene-dependent and $h r p$ gene-independent mechanisms. Mol. Plant-Microbe Interact. 14:785-792.

Okamoto, K., Nomura, T., Fujii, Y., and Yamanaka, H. 1998. Contribution of the disulfide bond of the A subunit to the action of Escherichia coli heat-labile enterotoxin. J. Bacteriol. 180:1368-1374.

Pallen, M. J., Penn, C. W., and Chaudhuri, R. R. 2005. Bacterial flagellar diversity in the post-genomic era. Trends Microbiol. 13:143-149.

Qian, W., Jia, Y., Ren, S. X., He, Y. Q., Feng, J. X., Lu, L. F., Sun, Q., Ying, G., Tang, D. J., Tang, H., Wu, W., Hao, P., Wang, L., Jiang, B. L., Zeng, S., Gu, W. Y., Lu, G., Rong, L., Tian, Y., Yao, Z., Fu G., Chen, B., Fang, R., Qiang, B., Chen, Z., Zhao, G. P., Tang, J. L., and He, C. 2005. Comparative and functional genomic analyses of the pathogenicity of phytopathogen Xanthomonas campestris pv. campestris. Genome Res. 15:757-767.

Raczko, A. M., Bujnicki, J. M., Pawlowski, M., Godlewska, R., Lewandowska, M., and Jagusztyn-Krynicka, E. K. 2005. Characterization of new DsbB-like thiol-oxidoreductases of Campylobacter jejuni and Helicobacter pylori and classification of the DsbB family based on phylogenomic, structural and functional criteria. Microbiology 151:219-231.

Riddles, P. W., Blakeley, R. L., and Zerner, B. 1979. Ellman's reagent: 5,5'-dithiobis(2-nitrobenzoic acid)—a reexamination. Anal. Biochem. 94:75-81.

Rossier, O., Van den Ackerveken, G., and Bonas, U. 2000. HrpB2 and HrpF from Xanthomonas are type III-secreted proteins and essential for pathogenicity and recognition by the host plant. Mol. Microbiol. 38:828-838.

Ryan, R. P., Fouhy, Y., Lucey, J. F., Jiang, B. L., He, Y. Q., Feng, J. X., Tang, J. L., and Dow, J. M. 2007. Cyclic di-GMP signalling in the virulence and environmental adaptation of Xanthomonas campestris. Mol. Microbiol. 63:429-442.

Sambrook, J., Fritsch, E. F., and Maniatis, T. 1989. Molecular Cloning: A Laboratory Manual, 2nd ed. Cold Spring Harbor Laboratory, Cold Spring Harbor, NY, U.S.A.

Sandkvist, M. 2001. Type II secretion and pathogenesis. Infect. Immun. 69:3523-3535.

Schafer, A., Tauch, A., Jager, W., Kalinowski, J., Thierbach, G., and Puhler, A. 1994. Small mobilizable multi-purpose cloning vectors derived from the Escherichia coli plasmids pK18 and pK19: Selection of defined deletions in the chromosome of Corynebacterium glutamicum. Gene 145:69-73.

Shevchik, V. E., Bortoli-German, I., Robert-Baudouy, J., Robinet, S. Barras, F., and Condemine, G. 1995. Differential effect of $d s b A$ and $d s b C$ mutations on extracellular enzyme secretion in Erwinia chrysanthemi. Mol. Microbiol. 16:745-753.

Starr, M. P. 1981. The genus Xanthomonas. Pages 742-763 in: The Pro- karyotes, Vol. 1. M. P. Starr, H. Stolp, G. H. Truper, A. Balows, and G. H. Schlegel, eds. Springer-Verlag, Berlin.

Stenson, T. H., and Weiss, A. A. 2002. DsbA and DsbC are required for secretion of pertussis toxin by Bordetella pertussis. Infect. Immun. 70:2297-2303.

Tang, J. L., Gough, C. L., Barber, C. E., Dow, J. M., and Daniels, M. J. 1987. Molecular cloning of protease gene(s) from Xanthomonas campestris pv. campestris: Expression in Escherichia coli and role in pathogenicity. Mol. Gen. Genet. 210:443-448.

Tang, J. L., Liu, Y. N., Barber, C. E., Dow, J. M., Wootton, J. C., and Daniels, M. J. 1991. Genetic and molecular analysis of a cluster of $r p f$ genes involved in positive regulation of synthesis of extracellular enzymes and polysaccharide in Xanthomonas campestris pathovar campestris. Mol. Gen. Genet. 226:409-417.

Tinsley, C. R., Voulhoux, R., Beretti, J. L., Tommassen, J., and Nassif, X. 2004. Three homologues, including two membrane-bound proteins, of the disulfide oxidoreductase DsbA in Neisseria meningitidis: Effects on bacterial growth and biogenesis of functional type IV pili. J. Biol. Chem. 279:27078-27087.

Turner, P., Barber, C. E., and Daniels, M. J. 1985. Evidence for clustered pathogenicity genes in Xanthomonas campestris pv. campestris. Mol. Gen. Genet. 199:338-343.

Urban, A., Leipelt, M., Eggert, T., and Jaeger, K. E. 2001. DsbA and DsbC affect extracellular enzyme formation in Pseudomonas aeruginosa. J. Bacteriol. 183:587-596.

Vincent-Sealy, L. V., Thomas, J. D., Commander, P., and Salmond, G. P. 1999. Erwinia carotovora DsbA mutants: Evidence for a periplasmicstress signal transduction system affecting transcription of genes encoding secreted proteins. Microbiology 145:1945-1958.

Watarai, M., Tobe, T., Yoshikawa, M., and Sasakawa, C. 1995. Disulfideoxidoreductase activity of Shigella flexneri is required for release of Ipa proteins and invasion of epithelial cells. Proc. Natl. Acad. Sci. U.S.A. 92:4927-4931.

Xu, R. Q., Blanvillain, S., Feng, J. X., Jiang, B. L., Li, X. Z., Wei, H. Y., Kroj, T., Lauber, E., Roby, D., Chen, B., He, Y. Q., Lu, G. T., Tang, D. J., Vasse, J., Arlat, M., and Tang, J. L. 2008. AvrAC ${ }_{\mathrm{Xcc8004}}$, a type III effector with a leucine rich repeat domain from Xanthomonas campestris pathovar campestris confers avirulence in vascular tissues of the Arabidopsis thaliana ecotype Col-0. J. Bacteriol. 190:343-355.

Yanisch-Perron, C., Vieira, J., and Messing, J. 1985. Improved M13 phage cloning vectors and host strains: Nucleotide sequences of the M13mp18 and pUC19 vectors. Gene 33:103-119.

Yu, J., Webb, H., and Hirst, T. R. 1992. A homologue of the Escherichia coli DsbA protein involved in disulphide bond formation is required for enterotoxin biogenesis in Vibrio cholerae. Mol. Microbiol. 6:1949-1958.

Yu, J., Edwards-Jones, B., Neyrolles, O., and Kroll, J. S. 2000. Key role for DsbA in cell-to-cell spread of Shigella flexneri, permitting secretion of Ipa proteins into interepithelial protrusions. Infect Immun. 68:6449-6456.

Zhang, H. Z., and Donnenberg, M. S. 1996. DsbA is required for stability of the type IV pilin of enteropathogenic Escherichia coli. Mol. Microbiol. 21:787-797.

\section{AUTHOR-RECOMMENDED INTERNET RESOURCES}

National Center for Biotechnology Information website:, www.ncbi.nlm.nih.gov

Center of Biological Sequnce Analysis TMHMM server: www.cbs.dtu.dk/services/TMHMM 